\title{
ADVANCING CAREER COUNSELLING RESEARCH AND PRACTICE USING A NOVEL QUANTITATIVE+QUALITATIVE APPROACH TO ELICIT CLIENTS' ADVICE FROM WITHIN
}

\author{
J. G. Maree \\ Department of Educational Psychology \\ University of Pretoria \\ Pretoria, South Africa \\ e-mail: kobus.maree@up.ac.za
}

\section{ABSTRACT}

This article reports on the results of providing career counselling to a purposefully selected firstyear university student experiencing career indecision. An integrative approach based on qualitative and quantitative techniques was used to engage the student (the research participant) in conversations, reflections and meta-reflections on how to find meaning and purpose in his current studies and also in his future career-life. An intrinsic, single-case study involving a purposefully selected participant and the use of two newly developed instruments was undertaken to demonstrate the practical implementation of the novel approach. The intervention helped the participant identify his career-life themes and later choose a field of study that would enable him to fit work into his life, design and live a successful life and make meaningful social contributions. Future research should investigate the longitudinal value of the approach and its use in group contexts.

Keywords: career counselling, a quantitative+qualitative approach, eliciting advice from within, Career Interest Profile, Maree Career Matrix, subjective and objective methods

\section{THEORETICAL BACKGROUND}

Numerous factors contribute to the growing insecurity and feelings of uncertainty among workers in the $21^{\text {st }}$ century. Career choice decisions are becoming more complex because of the increasing difficulty in predicting the evolution of the occupational world. Bańka and Hauziń (2015, 34) maintain that

"[m]aking life changing decisions in a chaotic reality is increasingly difficult and there is always a risk of failure, be it simply the assessment of pursued goals and sought-after values or in the goals themselves. Therefore, it is no surprise that nowadays people link the most important life issues with career decision.”

According to the Bureau of Labor Statistics (BLS) (2016) in the United States of America, Americans on average change work 12 times in their career-lives. Reasons for the rapid movement between jobs include the inability to maintain a work-life balance and the 
redundancy of once-useful skills and abilities (Doyle 2016). Doyle (2017, 1) states that “upgrading one’s employment status has [therefore] become an ongoing process”, while Chiaradonna (2017) adds that researchers are predicting that Americans will on average have more than 14 different jobs or work for more than 14 different employers during the course of their work-lives. He maintains that staying in the service of one employer is becoming the exception rather than the rule and that the social agreement, contract, or arrangement between employers and workers has changed radically. Employees' biggest challenge today is to find a way to stay relevant and to merge their work and life roles. What they have to do therefore is embark on a "journey of personalized growth" (Chiaradonna 2017, 1) where increasing selfawareness is a crucial requirement.

The often bewildering changes in the world of work are giving rise to increased uncertainty, not only among current workers but also among future workers (such as students). This uncertainty is rendering it more difficult to make long-term career decisions such as whether a particular career will be compatible with a person's unique traits, enable him $^{1}$ to develop in that career and to actualise his central life themes in that career. Anthony (in Wolfe 2017, n. p.) argues that the term "life planning" is more appropriate today than "career planning”, while Wolfe (2017) contends that it is fruitless to try to subsume people's lives, careers and job titles into a single concept. He adds that it has become necessary for people to cultivate competences that cannot easily be replicated by artificial intelligence and machines and computers. They need, accordingly, to develop and use the following five critical skills (C’s): critical thinking, curiosity, creativity, collaboration and communication. Since these skills are currently beyond the capability of machines and computers, their acquisition by people will help them become more employable, more career resilient and more secure in the workplace - which is far more important than merely finding employment.

Career counsellors need to reflect critically on their theory and practice and reconsider their individual as well as their collective response to developments in information communication technology (ICT). These developments are associated with the Fifth Information Wave or the digital revolution (Gurri 2013) and the Fourth Industrial Revolution with its impact on the global economy (Maree 2015). Such reflection is necessary to enable career counsellors to help the employed as well as the unemployed and also prospective workers (including students) contend with the numerous challenges and accompanying uncertainty and insecurity brought about by the far-reaching changes in the world of work. The capability to help people resolve career indecision at various stages of their career-lives has thus become an even more fundamental part of career counselling. 


\section{Career indecision}

Betz (1992), Kelly and Lee (2005) and Gati et al. (2011) maintain that career indecision signifies challenges or difficulties that preclude people from making appropriate career choice decisions. Hartung $(2015,1)$ contends that “[d]ifficulties with career decision ranks among the most common reasons people seek career counseling”. This contention is consistent with my own experiences in career counselling. In a previous article (Maree 2016), I distinguished between two broad groups of people experiencing transitions often leading to career indecision and the inability to make appropriate career choices. First, in many instances, people transition in a natural or logical manner (e.g. when they have to choose a type of school, subjects, study field, or type of tertiary training). Second, in other instances, people may begin to doubt whether they made the "right" choices (e.g. taking mathematics instead of mathematical literacy or studying to become a dietician rather than a teacher). Their doubt may stem from a combination of factors such as failing certain subjects and not being selected for a sought-after field of study such as medicine or occupational therapy. They may also experience frustration at not being able to master the subject content in a certain field of study, or they may discover during their studies that the future career prospects in their chosen field of study are not good, or they may discover fields of study of greater interest to them (fields they had not known about previously). More often than not, students experiencing indecision blame their indecision on lack of knowledge of the world of work or of what certain fields of study actually entail. Such indecision could arise also from inadequate career counselling, from not having received any career counselling at all, from inappropriate or undue parental interference, from peer pressure, from personal problems experienced during their study year(s), or from changed personal circumstances.

\section{Dealing with career indecision}

Various interventions aimed at treating career indecision have been researched and developed. Gati, Krausz and Osipow (1996), Forner (2007) and Picard (2012), for instance, advocated the identification and establishment of a hierarchy of the causes or sources of career indecision followed by appropriate interventions and strategies to deal with these causes or sources. Creed, Prideaux and Patton (2006), as well as Betz and Luzzo (1996), linked career indecision to selfefficacy issues. Lent et al. (2016) drew on Lent and Brown's (2013) new social cognitive career theory (SCCT) of career self-management (CSM) (which covers a wide variety of adaptive career-related behaviours used by people to adapt to occupational and personal contexts throughout their lifespan) to examine factors related to career exploration and decision making. Surprisingly, no consensus has emerged on a theoretical approach to dealing with career 
indecision (Miller and Rottinghaus 2014). Hartung $(2015,3)$ cites a number of researchers (e.g. Heppner et al. 2004; Masdonati, Massoudi and Rossier 2009) to back up his contention that "[i]ndividual career counseling is effective in decreasing career decision-making difficulties and increasing career decidedness”. Whiston and Rose (2013), too, argue that identifying career decision-making difficulties is important for designing and scaffolding strategies and interventions to deal with the problem. Kelly and Shin (2009) contend that using a blend of developmentally based career counselling interventions (to improve clients' adaptability) and cognitive-based interventions (to decrease undesirable or adverse career choice views and feelings) may help moderate the negative impact of lingering career indecision. Jantzer, PriceStalides and Rottinghaus (2009) argue that career indecision should be seen as a "standard" facet of growing up (developing) and that bolstering young people's career decision-making self-efficacy will augment their sense of self.

The storied or narrative approach is a unique theoretical approach and style of assessment and intervention that is being used more and more to deal with career choice challenges (including career indecision). The rationale for this approach has been the global shift from an overly "positivist” to a "positive” approach to career counselling during the past few decades. This major paradigm shift was initiated by Savickas (1993; 2011a) who merged the personenvironment fit (differential) paradigm with the developmental and narrative/psychodynamic/storied paradigms to construct a true meta-theory, namely career construction counselling. He also devised an associated assessment and intervention instrument (the Career Construction Interview (CCI)) and demonstrated the value of using a combined and quantitative qualitative approach to career counselling rather than just a quantitative approach on its own. Career and self-construction (based on Guichard's (2009) self-construction theory) counselling is premised on the view that it is better to help people script (and rescript) their career-life stories rather than testing them and telling them what career to choose ("three interviews and a cloud of dust” (Crites 1981, 49). This approach facilitates the eliciting of life stories and the harnessing of reflection and reflexivity. It promotes the development of a healthy and stable sense of self and, ultimately, gives people the opportunity to participate actively in their career and self-construction and in accepting authorship of their developing career-life stories. In my article on career indecision (Maree 2016), I reported on the results of a singlecase study (based on a qualitative, interpretive paradigm) in which I used the Career Construction Interview (CCI) to collect qualitative data to help a postgraduate student deal with career indecision. Using Savickas's eight-step strategy to assist the student to complete her life portrait, I could help her overcome her career indecision.

Bujold (2004), Maree (2016), Obi (2015), Savickas (2009; 2011b), as well as Taber et al. 
(2011) and others, too, have demonstrated the power of drawing on career construction theory (Savickas 2005) and life construction theory (Guichard 2009) to resolve career indecision. The approach is based the elicitation and use of young people's micro-, meso- and macro career-life stories not only to shape their career-related development but also to help them overcome their career indecision by changing their career-related reasoning, reflecting and decision-making style (Maree 2013).

In the present study, I too drew on CCT and SCT as the conceptual framework for the intervention. I included both quantitative and qualitative strategies and techniques in accordance with the three theoretical approaches underlying career construction counselling, namely the differential (using tests to help people find a satisfactory "fit" between their personality traits and the work environment), the developmental (promoting people's career development) and the dynamic (uncovering people’s key, deep-seated motivations and careerlife themes, which can promote career choice purposefulness, decisiveness and decidedness) approaches.

\section{Using an integrative, qualitative+quantitative approach to deal with career indecision}

A brief review of the career counselling theories that have guided career counselling practice over the past 25 years or so reveals that theorists and practitioners have increasingly moved from drawing on a "traditional” (quantitative or "objective”) approach in relative isolation towards accepting the value of a "postmodern" (qualitative or "subjective") approach. Consequently, the integrative approach - which accords equal value and relevance to quantitative and qualitative assessment and intervention - is being used increasingly in developed countries but is only gradually gaining traction in non-developing cultures. Maree (2014), Savickas (2011a; b), Hartung (2015) and others have consistently stressed the importance of using creative methods and interventions to help people reflect on their careerlife stories (and reflect on their reflections) and, in doing so, enable them to elicit authentic advice from within on how to overcome career-related indecision, diffidence and self-doubt. Authentic advice correlates positively with the acceptance of self-authorship of one's careerlife stories and it advances choice-making that consider internal experiences such as opinions, volitions, feelings (Kernis and Goldman 2006; White and Tracey 2011) and wellbeing (Wood et al. 2008). Savickas (2011a) argues that forward movement facilitates the resolution of career indecision and helps “undecided”, “passive”, or “stuck” people become active, that is, make a decision, even in challenging circumstances. Put differently, people should be encouraged and helped to resolve career indecision by constructing themselves and their careers actively thereby 
promoting the design of successful lives.

As mentioned earlier, the "new" approach draws on CCT, SCT and, ultimately, on the inclusive life design paradigm (Savickas et al. 2009) - the first-ever true career counselling paradigm. These three theories are based broadly on a constructivist approach, more particularly, the notions of social constructionism and/or social constructivism. The three levels of intervention in the new approach are, a. career education, b. vocational guidance and c. career counselling and life designing (Duarte 2017). Career education involves the provision of information of various kinds about the world of work - for instance, information about tertiary training institutions, about other training opportunities, about subject choices and about what exactly different careers entail. From a vocational guidance perspective, career counsellors provide information of i) a psychosocial and ii) a psychoeducational kind. Psychosocial information includes information on the influence of assessees' social context and environment and also on the influence of psychosocial factors on their functioning. Its aim is to enhance people's psychological and social functioning, especially in relation to the impact of their functioning on their career choices. Psychoeducational information helps assessees better understand and "manage" their career choices. The first two types of information help people reflect on their future careers (how careers can be chosen and pursued), bearing in mind particular requirements that are unique to their contexts such as the choice of a school, a subject set, or a field of study, or the construction of their self-concept and self-image (formerly referred to as a "personality profile"). Also at issue is the level of adaptability and resilience that will stand them in good stead in a future workplace. Briefly summarised, career counselling and life design information helps people reconsider the role of work in their career-lives (instead of the other way around) and helps them identify and elaborate their central life themes - future prospects that can add a sense of purpose and meaning to their career-lives.

In the second part of this article, I discuss a case study that demonstrates the practical applicability of the "new" approach through the implementation of two new career counselling instruments and their associated techniques and strategies. The Career Interest Profile (CIP) (Maree 2015), a qualitative or narrative career inventory, which was developed over a period of 30 years and its quantitative counterpart, the Maree Career Matrix (MCM) (Maree and Taylor 2016a; b), which was developed over the past 15 years or so. The MCM, with its excellent psychometric properties, was included in the South African Professional Board for Psychology's list of approved tests in November, 2015. The two instruments can be used to facilitate integrative, qualitative+quantitative career counselling in group-based as well as individual (one-on-one) contexts. This qual+quan blend works remarkably well, even in seriously disadvantaged areas (Maree 2015). In individual contexts, the CIP can be used either 
alone or in conjunction with the MCM. Integrative use of the two instruments also facilitates triangulation, crystallisation and trustworthiness.

\section{Rationale for the study}

Many students either fail their first year at university, decide to change from one field of study to another, or drop out in South Africa as well as elsewhere in the world (Morgan and Ness 2003; Maree 2012; Picard 2012). The situation in South Africa is unusual in that many topachieving students are denied access to highly sought-after fields of study such as medicine, dentistry, veterinary sciences, physiotherapy and occupational therapy largely because of what is referred to as "black empowerment" or affirmative action - a situation that has prevailed since 1994. Because sufficient transformation has not been achieved in terms of enrolment in different fields of study at universities, some people believe that the current situation should be perpetuated until the ideals of "access”, "fairness" and "social justice” have been realised. These restitutive strategies often lead to intense frustration and feelings of disempowerment by some top-achieving students (whites and Indians in particular) who feel that they are the victims of "unfair discrimination". More research needs to be done on how affected students a) experience this situation and b) deal with the situation.

\section{Working assumption}

This study was based on the assumption that a qualitative+quantitative approach using two new career counselling instruments would promote decision making (resolve career indecision) and bring about change in the career-life story of a first-year university student who had sought career counselling.

\section{Personal bias}

I am a professional psychologist with specialist knowledge of and extensive national and international experience and acknowledgement in the field of career counselling. Against this background, I can confidently express my firm belief in the value of a qualitative (storied) approach to career counselling, However, I also believe in the power of an integrative, qualitative+quantitative approach to career counselling and its potential to promote a sense of purpose and meaning-making in people’s lives - both in individual and group contexts.

\section{Aims of the study}

This study sought answers to the following questions: 
a. How did a qualitative+quantitative approach (using two new career counselling instruments) help a first-year university student elicit advice from within himself?

b. What changes did the intervention foster?

c. What factors prompted these changes?

\section{METHODOLOGY}

\section{Participant and context}

The participant was purposively selected to take part in the case study. At the time of the study, Kyle (a pseudonym) was a 19-year-old Afrikaans-speaking young man from a marginally above-average educational, social and economic environment. The selection criteria for participation in the study called for a first-year university student who had stated his or her intention to change courses and enrol for a different field of study and who had expressed a need for career counselling. Kyle had requested such counselling, had completed Grade 12 eight months prior to the study and had enrolled for a BSc degree in Biological Sciences after learning that he had failed to meet the requirements for acceptance into medical studies. This failure made him despondent and depressed. He felt as if he was “drifting and going nowhere”. In his own words: "Help me choose a field of study that will better 'suit' me. One that will take me to a career that 'fits' me better than the one I am currently studying for. Give me a broader perspective on the occupational world. Maybe even a career that I have never thought about; one that is totally new to me."

\section{Mode of inquiry}

A naturalistic inquiry (embedded in an interpretive, inductivist paradigm (Bryman 2016)) was conducted. It took the form of an explorative, descriptive, instrumental, individual case study in a one-on-one research setting and had an integrative, qualitative+quantitative design (using the $M C M$ and the $C I P$ ).

\section{Data-gathering instruments}

\section{Quantitative assessment}

The Maree Career Matrix (MCM) (Maree and Taylor 2017a; b) and the South African Vocational Interest Inventory (SAVII) (Du Toit 1992) were administered. The MCM (Maree and Taylor 2016a; b) was developed and standardised in South Africa between 2002 and 2015 and accredited with excellent psychometric properties (Maree and Taylor 2017a, b), while the 
SAVII (Du Toit 1992) was standardised in South Africa in 1992 and accredited with acceptable psychometric properties. The tests were scored by me and the qualitative data coded by me and an external coder to ensure inter-rater validity. The aim was to ensure that the identified themes accurately reflected the data thereby improving the authenticity of the deductive process.

\section{Qualitative assessment}

The Career Interest Profile (CIP, Version 5) (Maree 2015) was used to gather qualitative (narrative) data in terms of the narrative paradigm (the CIP is a wholly qualitative instrument, not a psychometric instrument). The CIP consists of a number of carefully structured questions to elicit and promote reflection, reflexivity and self-reflexivity (Hsiung 2008) with regard to clients' career-life themes, their values, their interests and, most importantly, their advice to themselves. It has four parts: biographical details, questions on family influences and workrelated information (Part 1); six career choice questions (Part 2); a question on career category preferences and dislikes (Part 3); and 15 career-life story narrative questions (Part 4). The CIP provides counsellors with a starting point for identifying, discussing and analysing central career-life themes and career-related issues in greater depth. Most importantly, it enables counsellors to listen for clients' (core) career-life stories instead of merely listening to their stories.

The participant (Kyle) was requested also to write an autobiographical narrative entitled "My story" and to bring it with him on the day of the assessment.

\section{Intervention}

The intervention comprised three different, individual sessions. In Session 1 (the initial interview - 120 minutes), Kyle’s career-life story was elicited, while Session 2 (authorisation - 60 minutes) was devoted to the interpretation of Kyle’s story. In Session 3 (30 minutes), action and forward movement were discussed and organised.

\section{Rigour of the study}

A number of strategies were implemented to improve the trustworthiness of the research with regard to the obtaining, preparing, organising and reporting of the data (Elo et al. 2014). For instance, triangulation and crystallisation were promoted by obtaining quantitative and qualitative data using a combination of quantitative and qualitative strategies and techniques. In addition, participant explanations and reflections were written down and reported in as much detail as possible, including potentially contradictory information. An experienced, external coder coded the qualitative data and reassessed the findings to avoid the selective use of data. 
The participant was given an opportunity to verify the inferences drawn and to clarify possible misunderstandings - only evidence-based inferences were considered (adapted from Creswell 2005). In order to deal with the difference between me as a researcher and as a practitioner (and the possible influence this may have had on the research), three strategies were implemented to reduce possible bias and increase the credibility and quality of my analysis (Patton 2002), namely data triangulation, theory triangulation and methodological triangulation.

My subjective immersion in the study may have influenced my observations. Hay-Smith et al. (2016) argue that it is impossible to separate the role of researcher and practitioner completely. The adequate planning, implementation, monitoring and reporting of strategies to deal with the ethical and methodological consequences of dual roles during research are required. I accordingly a) implemented a standardised informed consent process to make sure that the rights of the participant were respected at all times; b) I took care to observe my ethical code; c) I discussed my findings with an experienced colleague to help me maintain a keen sense of "objectivity"; d) I made sure that only I (a researcher-practitioner with 35 years' experience) obtained and used the data; and e) I maintained an honest and open dialogical relationship with the participant about all aspects of the study (Kewley 2006). I was at all times aware that that the participant might have been influenced (consciously or subconsciously) by his desire to please me by giving the “right” responses (Sieck 2012).

\section{Ethics}

Permission to conduct the study was granted by the Review Board of the University of Pretoria. Informed written informed consent was obtained from the participant for the analysis and (anonymous) reporting of the research. I guaranteed the confidentiality of the data and the findings, explained and clarified all aspects of the research procedure (including my comments) throughout the study and allowed sufficient time for (self-) reflection at all stages of the study

\section{FINDINGS}

\section{Outcomes of the quantitative part of the assessment}

a. The Maree career Matrix (MCM): Engineering and the built environment; Medical and/or paramedical services; Executive management practice; Adventure, plants, animals and the environment; as well as Mathematics and/or the accounting industry fall in the MCM's “Go for it!” quadrant. Categories that fall in this quadrant indicate definite, clearly defined interests and confidence levels, which means that Kyle (the participant) at the time of the study was interested in and believed that he would succeed in careers in these categories. 
Consequently, he was encouraged to do a job analysis of the careers associated with these categories. Specific careers Kyle scored as having both high interest in and confidence about were those of a civil, industrial or mechanical engineer; architect; construction manager; biokineticist; draughtsperson; pharmacist; project manager; physiotherapist; medical doctor; land surveyor; and city and regional planner.

b. The SAVII (Du Toit 1992) yielded a low, flat, undifferentiated profile indicating that Kyle showed a preference for

- buying, selling, promotion, persuasion and management (acting in an enterprising manner in the business world);

- $\quad$ nature (plants and animals);

- construction, service and maintenance, repair work, engineering and technology; and

- medical and paramedical fields.

While the two "sets" of quantitative results correlated strongly positively, the MCM yielded much richer and more extensive data than the SAVII.

\section{Outcomes of the qualitative part of the assessment}

The three specific careers Kyle thought he would like most: (Kyle’s verbatim responses have been only lightly edited to preserve the authenticity of what he said). His responses to my request for elaboration appear between brackets.

1. Radiologist ("A friend of ours is a radiologist; he is very rich. I also want to make much money so I can live without financial worries.”)

2. Engineer/Electrician ("I have always been good at mechanical and practical things.”)

3. Businessman ("I want to make a lot of money; I have always been told that I have a good sense of business.”)

The three specific careers Kyle thought he would like least:

1. Singer ("I cannot sing and on top of that I hate being passive all the time.")

2. Computer specialist ("I have never liked working with computers. I merely use a computer to do my assignments.”)

3. Journalist ("I won't enjoy sitting still and writing most of the time. It also seems to me that much about this career is not guaranteed. The whole idea of interviewing others and often being insulted does not appeal to me either.”)

His responses to some of the questions in the last part of the CIP appear below. (Due to space constraints, only selected responses are given.) 
1. “How can I be of use or of help to you?” (Maree 2017a; b; Savickas 2011a).

"Give me a broader idea regarding careers that will fit my personality. Something that I wasn't even aware of. It seems as if I may have been following an unworkable dream that is not really me and I feel unsure and dispirited at present. I don't know what to do any longer. Hopefully you can recommend something that will excite me again ... something to work and live for.” (This comment is consistent with Miller and Rottinghaus' (2014) finding that searching for a sense of meaning and purpose in people's lives mediates the association between experiencing career indecision and being anxious.)

2a. "What are your

i) greatest strengths?”

"Good at numbers - always the first to solve maths problems. I am good at fixing mechanical things. Get on very well with others, care a lot about others, never hurt others. I always try to understand the bigger picture; rise above pettiness. I am organised and structured."

"I am a positive, happy kind of person ... at least, that was the case until recently." Asked to explain what he meant (deconstruction of micro-stories), Kyle said: "Struggling so much to find what the 'right' career is for me, is beginning to make me feel discouraged and unhappy. That is not who I am and I want to resolve the matter. That is why I am consulting you."

"I normally enjoy solving problems."

"I have a strong sense of what is right and what is wrong, I am soft-hearted and I really care about people.”

ii) “areas for development?”

"I currently lack the motivation needed to succeed at university" (He lacks motivation to study hard at present) "because I am no longer sure about my field of study and, in fact, my whole future. That is why I feel so disheartened at present. I need to make a change.” (He shows a desire to reconstruct his story)

2c. "How do other people see you?"

"Easy to get on with, likeable, adaptable, a leader, nice to be with, principled, not swayed by the group, very good at numbers and at fixing mechanical things."

4a. "Whom did you admire or who were your role models when you were young? Why?"

"Michael Schumacher. I admired his passion for cars and driving (I love cars!), his resilience, his ability to bounce back after setbacks."

"Sergei Constance. The best body builder of all times, he was disciplined, motivated, principled and he had the ability to deal with disappointments and setbacks and come out stronger as a result.”

After completing the CIP, Kyle insisted on listing another role model:

"A friend of my parents. He was a radiologist and we visited him on his game farm. He was such a compassionate, positive man. I was awestruck when I saw his massive house, the farm, the animals. He had everything, I thought. I always wanted to make as much money as he did. He seemed so untouchable ... so much in control of his situation, so much money ... he could buy almost everything.") (Kyle gives some evidence of being stuck in the "tentative" phase of the developmental stage of career development - Super 1957.)

6a. "What are your favourite quotations?” (Kyle’s advice to himself; his explanation appears between brackets.) 
"Only time will tell.” (Deconstructing his micro-story: “That is the real purpose of today's visit: so you can help me decide what to do.”)

"Do your best and God will do the rest." ("I am blessed with father’s common sense; I have always believed that one should always stay positive and focus only on what one can change. It is senseless to worry about the 'inevitable'.”)

"Float like a butterfly and sting like a bee." ("Try not to get caught up in unimportant things and when you do things, be serious and do the best you can.”)

10. "What things hurt you most when you were young and that you did not want others to suffer?"

a. "I was always very active and enthusiastic about taking part in sport; often trying to do too much too fast ... that led to a number of painful injuries." (Upon further questioning, he replied: "I admit that I may sometimes be acting overhastily; not always considering all aspects of challenges.”)

b. "I was always interested in cars and other mechanical things." "Experimenting with things sometimes did not yield the results I was hoping for, for example trying to drive our car at a very young age and bumping into the wall of our garage.”)

c. "I couldn't stand seeing people fight over silly things. I still cannot.” ("There are much more important things to do than to nit-pick about petty things.”)

The qualitative responses obtained from the CIP and, importantly, Kyle's reflections on his responses, revealed his interests, traits and career preferences. They also revealed his key career-life themes and helped him regain a sense of purpose and meaning in his career-life (Savickas 2014; see Table 1). He and I used the integrated information to co-construct fields of study that could help him acquire a sense of purpose and meaning in life. To promote triangulation, Kyle was frequently invited to reflect on the intersection between the quantitative and the qualitative information "results". Although the fields of study obtained from perusing the quantitative data corresponded closely with the fields of study obtained from perusing the qualitative data, identifying deep-seated central life themes was possible only by carefully examining and repeatedly reflecting on the qualitative data.

(Kyle's response patterns were consistent throughout and a strong positive relationship emerged between the quantitative and the qualitative outcomes - see Table 1).

Table 1: Integrated outcomes: identified life themes and associated fields of study

\begin{tabular}{|l|l|l|l|}
\hline \multirow{2}{*}{ Theme(s) and subthemes identified } & \multicolumn{1}{|c|}{$\begin{array}{c}\text { Associated field(s) of } \\
\text { study }\end{array}$} & \multicolumn{2}{|c|}{ Source(s) of data } \\
\cline { 3 - 4 } & \multicolumn{1}{|c|}{ Qualitative } & \multicolumn{1}{c|}{ Quantitative } \\
\hline A. Leadership abilities & Business management & CIP responses & MCM, SAVII \\
1. Excellent interpersonal & Economics & $\begin{array}{l}\text { and related } \\
\text { reflections } \\
\text { relationships }\end{array}$ & Kyle's life story/ \\
2. Problem-solving orientation & & reflections/meta- \\
3. Positivity & & reflections \\
4. Supporting others & & \\
5. Ability to remain calm & & \\
6. Natural leader & & \\
7. Natural "kindness" & & \\
\hline
\end{tabular}




\begin{tabular}{|c|c|c|c|}
\hline \multirow{2}{*}{ Theme(s) and subthemes identified } & \multirow{2}{*}{$\begin{array}{l}\text { Associated field(s) of } \\
\text { study }\end{array}$} & \multicolumn{2}{|c|}{ Source(s) of data } \\
\hline & & Qualitative & Quantitative \\
\hline $\begin{array}{l}\text { B. Natural sciences + practical- } \\
\text { technical orientation } \\
\text { 1. Adept at and interest in } \\
\text { numbers } \\
\text { 2. Mechanical ability and interest }\end{array}$ & $\begin{array}{l}\text { Engineering (Industrial. } \\
\text { Mechanical) } \\
\text { Construction management } \\
\text { Geomatics/ Surveying } \\
\text { City and regional planning } \\
\end{array}$ & & \\
\hline $\begin{array}{l}\text { C. Business/ Entrepreneurship } \\
\text { orientation } \\
\text { 1. Natural leadership abilities } \\
\text { 2. Common sense } \\
\text { 3. Ability to manage }\end{array}$ & $\begin{array}{l}\text { Business or marketing } \\
\text { management } \\
\text { Industrial psychologist/ } \\
\text { Human resources } \\
\text { management } \\
\text { Entrepreneurship } \\
\text { Economist } \\
\text { Company CEO }\end{array}$ & & \\
\hline $\begin{array}{l}\text { D. Sport, adventure and the outdoors } \\
\text { orientation } \\
\text { 1. Love for the outdoors } \\
\text { 2. Enjoys participating in sport } \\
\text { 3. Desire to remain fit and healthy }\end{array}$ & $\begin{array}{l}\text { Agribusiness } \\
\text { management } \\
\text { Sports management } \\
\text { Nature conservation } \\
\text { Wild game farming } \\
\text { Biokinetics } \\
\text { Farming } \\
\text { Lodge management }\end{array}$ & & \\
\hline E. Interest in medical matters & $\begin{array}{l}\text { Medicine } \\
\text { Dentistry } \\
\text { Pharmacy }\end{array}$ & & \\
\hline $\begin{array}{l}\text { F. Love for others } \\
\text { 1. Compassion } \\
\text { 2. Caring attitude } \\
\text { 3. Support for the underdog } \\
\text { G. Insecurity } \\
\text { 1. Overly strong desire to "make } \\
\text { money" }\end{array}$ & $\begin{array}{l}\text { Minister } \\
\text { Psychologist }\end{array}$ & & \\
\hline
\end{tabular}

Kyle and I subsequently co-constructed the following identity statement for him: "I am a natural leader, good at mathematics and mechanical matters; I am caring, compassionate, helpful and I love the outdoors." We also co-constructed the following vison and mission statement (Maree 2013; Savickas 2011b) for him: "I will analyse a number of fields of study and probably, depending on the outcome, become an industrial or mechanical engineer (occupational choice) so that I can utilise my strengths to make a contribution to the occupational world and society in general (social meaning) and in the process, find purpose and meaning in what I do and earn a decent salary (personal meaning).”

\section{Sequel}

At the conclusion of the third session, I asked Kyle how he had experienced the intervention.

a. "What did you enjoy about the intervention?"

"I have discovered why I was failing to make sufficient progress and why I felt so depressed about my field of study. I am eager to get going now.” (Co-constructing his career-story)

b. "What did you not enjoy?”

"Only the fact that I have 'wasted' time and energy on pursuing an impracticable dream.” 
c. "Is there anything else you want to say?"

"Only this: thank you for giving of your time and energy to help me. I have really benefitted from the sessions.”

\section{DISCUSSION}

This case study investigated the career counselling needs of a first-year university student wishing to change his field of study. A case study was discussed and used to examine the value of an integrative (qualitative+quantitative) approach to career counselling incorporating two new career counselling instruments and their associated techniques and strategies. The use of qualitative assessment instruments and techniques in conjunction with "traditional” quantitative assessment instruments is recommended as the latter instruments on their own often fall short of either bringing about change in people's career-lives or capturing or assessing qualitative changes in people’s self-narratives (Rehfuss 2009; Rehfuss and Di Fabio 2012).

The outcome of the study suggests that the integrative strategy was successfully implemented as it helped the student transition from one field of study to another, to rediscover a sense of purpose and meaning (Savickas 2016a; b) in his life and to transform dispiritedness into hopefulness. In addition, he discovered the shortcomings of basing the choice of a future career on "unauthentic” principles. By eliciting his career-life story and drawing on his own advice (under the guidance of a career counsellor), he was able to deal with a challenge that is often characteristic of his specific career phase and empowered to embark on a more "authentic" future career trajectory. Many researchers and practitioners have acknowledged the need to establish the rigour and efficiency of career counselling interventions, especially when an integrative, qualitative+quantitative approach is used as this approach is minimally covered in the literature (Blustein et al. 2008; Hartung 2011; Savickas 2011a; b; 2012; Subich 2011).

The approach followed in the present study supports Krumboltz's (1993) and PattersonMills' $(2014,24)$ assertion that “[ $t$ ]here is no division between personal and career counselling ... personal and career counselling are one and the same” and validates the view that is unwise to attempt to differentiate between personal and career counselling and intervention. It also confirms Krumboltz' contention $(2015,3)$ that

\footnotetext{
"making a career decision is [not] the goal. Instead the goal should be to launch the client on an exploratory task of talking with lots of people, helping other people with whatever tasks they faced at the moment, reading interesting articles about future occupational trends, applying for whatever jobs happen to be open now, interviewing people who are happy with the work they are doing now and never making a permanent occupational choice."
}

The study also supports Xu and Tracey’s (2017) finding that willingness to undergo career 
counselling may well lead to increased interest in finding new information about the world of work. After the assessment, the participant's willingness to undertake thorough job analysis helped him better understand certain fields of study and decide which careers would most likely enable him to design a successful life and make meaningful social contributions. His chosen field of study and associated career would enable him to fulfil his career-related needs (e.g. work with figures, actualise his mechanical ability and lead people) and, most importantly, realise his life's purpose and find meaning in what he did (Duffy and Dik 2009). His most recent comments (roughly one year after the assessment) bear testimony to this:

"My friends have noted that I am my 'happy self' again. I have rediscovered my desire to study and my belief that the future is worth living for. Being an industrial engineer will enable me to not only do what I am interested in but also enable me to eventually enter an executive position so I can help others realise their potential.”

After the intervention, the participant became involved in a local outreach project where he presented extra classes over weekends to help learners achieve better marks in mathematics and physical science. A significant change in his career-life story was evident from his clearer sense of self and identity, further indicating the effectiveness of the intervention. Savickas et al. (2009) and Soresi et al. (2008) consider an intervention successful if it leads to significant changes in clients' career-life stories.

The study supports the view that a dynamic qualitative+quantitative approach to career counselling is needed - an approach that encourages people's imaginative thinking and the exploration of different possible selves (Guichard 2004; 2005; Oyserman, Bybee and Terry 2006; Savickas 2005; 2011a). Such an approach can also help ameliorate the disconcerting phenomenon of students dropping out and/or changing fields of study during or after their first year at university or other tertiary training institutions. The intervention enabled the career counsellor and the participant to heighten the participant's awareness of his "authentic" self, unveil his central career-life themes and subthemes and strengthen his career adaptability and career resilience in addition to illuminating his interests and related fields of study (Savickas 2001; 2005). Narrating his career-life story clearly helped the participant access and understand his deep-seated career-life themes. This provided a "biographical" bridge that he and the career counsellor could use to build, rebuild and enhance his sense of self. Ultimately, this helped him navigate a major career-related transition, which would stand him in good stead when confronted with work-related transitions in later life (Savickas 2001). Once the participant had regained a sense of purpose and meaning and what he wanted to do and become in life, his career indecision largely disappeared. This outcome confirms Miller and Rottinghaus (2014) and Olivera-Celdran's (2011) view that a sense of purpose and meaning in life diminishes career 
indecision and promotes wellbeing.

The theoretical stance and associated intervention advocated in this article demonstrates how Savickas’ meta-theory (integrating theoretical, narrative, differential and developmental perspectives) can be implemented pragmatically in a real-life context (Savickas 2015a, b). Furthermore, the participant's feedback provides “proof” of the success of the intervention style and corroborates the findings of Hartung (2015) and Masdonati, Massoudi and Rossier (2009), namely that individual career counselling can contribute meaningfully to the resolution of career choice indecision (Heppner et al. 2004).

\section{Limitations}

Even though I did my best to ensure that my own subjectivity (my immersion in the study), beliefs, feelings and values did not interfere with my analyses, the possibility still exists that I might not have been entirely successful. I acknowledge my inability to verify all the qualitative results objectively (Datt and Datt 2011). Moreover, I accept also that other researchers may have arrived at different conclusions after analysing the data.

\section{Advice to others who may wish to conduct this type of intervention and analysis}

First, it is important to accept the rationale for the implementation of an integrative approach to career counselling. Second, training in the assessment and intervention modality is essential. Third, supervision is needed the first time the assessment and the intervention are carried out. Fourth, meticulous planning of the approach is needed in group-based contexts in particular.

\section{Recommendations for future research}

The integrative approach to career counselling has been implemented successfully in developing countries such as South Africa and Lesotho, with indications that the approach meets the criteria for "evidence-based research and practice”. However, implementing the approach in group-based settings requires further investigation and, in addition, longitudinal research on the impact of the intervention in traditional as well as non-traditional contexts is required.

\section{CONCLUSION}

The approach discussed in this article can be used to promote best practice in career counselling for first-year students in particular who, for whatever reason, are unsure whether their chosen field of study is "appropriate”, meets their unique career-life needs and serves as a conduit for 
designing a successful life. The approach holds great promise as a strategy career counsellors can use to help clients deal with career indecision, make authentic career choices, rediscover a sense of self and identity, rekindle a "lost" sense of purpose and meaning and provide them with renewed hope for their future.

\section{ACKNOWLEDGEMENT}

I wish to thank Mr. Tim Steward for editing the text.

\section{NOTE}

1. Feminine and masculine pronouns (she, he, her, him, hers, his) should be regarded as interchangeable.

\section{REFERENCES}

Bańka A. and A. Hauziński. 2015. Decisional procrastination of school-to-work transition: Personality correlates of career indecision. Polish Psychological Bulletin 46(1): 34-44.

Betz N. E. 1992. Career assessment: A review of critical issues. In Handbook of counseling psychology, ed. S. D. Brown and R. W. Lent, 453-484. New York, NY: John Wiley.

Betz N. E. and D. A. Luzzo. 1996. Career assessment and the career decision-making self-efficacy scale. Journal of Career Assessment 4: 413-428.

Blustein D. L., A.C. Kenna, N. Gill and J. E DeVoy. 2008. The psychology of working: A new framework for counseling practice and public policy. The Career Development Quarterly 564: 294-308.

Bryman, A. 2016. Social research methods. Oxford, England: Oxford University Press.

Bureau of Labor Statistics BLS. 2016. https://www.bls.gov

Bujold C. 2004. Constructing career through narrative. Journal of Vocational Behavior 64: 470-484.

Chiaradonna, A. 2017. Staying relevant: Managing yourself and your career. https://register. gotowebinar.com/register/359872737676269315?utm_source=Sailthruandutm_medium=emailan dutm_campaign=Insights\%20-\%2017-05-28\%20-\%20Guestandutm_content=Aandutm_term= Insights\%20-\%20Guest\%20-\%20Smart\%20List\%20v3

Creed, P. A., L. Prideaux and W. Patton. 2006. Causal relationship between career indecision and career decision-making and self-efficacy: A longitudinal cross-lagged analysis. Journal of Career Development 33(1): 47-65.

Creswell, J. W. 2005. Educational research - planning conducting and evaluating quantitative and qualitative research. Upper Saddle River, NJ: Pearson Prentice Hall.

Crites, J. O. 1981. Career counseling. Models methods and materials. New York NY: McGraw-Hill.

Datt, S. and S. Datt. 2011. Limitations and weakness of qualitative research methodology. https://www.projectguru.in/publications-qualitative-research/

Doyle, A. 2016. Bureau of Labor Statistics BLS. https://www.thebalance.com/bureau-of-labor-statisticsbls-2059767

Doyle, A. 2017. How often do people change jobs? https://www.thebalance.com/ howoftendopeoplechangejobs2060467

Duffy, R. D. and B. J. Dik. 2009. Beyond the self: External influences in the career development process. The Career Development Quarterly 58: 29-43. 
Du Toit, L. B. H. 1992. Manual for the Jung Personality Questionnaire JPQ. Pretoria South Africa: HSRC.

Duarte, M. E. 2017 June. Sustainable decent work. Invited public lecture at University of Pretoria Pretoria South Africa.

Elo, S., M. Kääriäinen, O. Kanste, T. Pölki, K. Utriainen and H. Kyngäs. 2014. Qualitative content analysis: A focus on trustworthiness. SAGE Open: 1-10.

Forner, Y. 2007. L’indécision de carrière des adolescents [Career indecision among adolescents]. Le Travail Humain 703: 213-214.

Gati, I., R. Gadassi, N. Saka, Y. Hadadi, N. Ansenberg, R. Friedmann and L. Lisa Asulin-Peretz. 2011. Emotional and personality-related aspects of career decision-making difficulties: facets of career indecisiveness. Journal of Career Assessment 191: 3-20

Gati, I., M. Krausz and S. H. Osipow. 1996. A taxonomy of difficulties in career decision making. Journal of Counseling Psychology 434: 510-526.

Guichard, J. 2004. Se faire soi [Self-construction]. L'Orientation Scolaire et Professionnelle 3(3): 499534.

Guichard, J. 2005. Life-long self-construction. International Journal for Educational and Vocational Guidance 5: 111-124.

Guichard, J. 2009. Self-constructing. Journal of Vocational Behavior 75: 251-258.

Gurri, M. 2013. The revolt of the public and the crisis of authority in the new millennium. (Kindle DX version). Amazon.com.

Hartung, P. J. 2011. Career construction: Principles and practice. In Shaping the story: A guide to facilitating narrative career counselling, ed. J. G. Maree, 103-120. Pretoria, South Africa: Van Schaik.

Hartung, P. J. 2015. Career indecision: Practice brief. Alexandria VA: American Counseling Association.

Hay-Smith, E. J. C., M. Brown, L. Anderson and G. J. Treharne. 2016. Once a clinician always a clinician: A systematic review to develop a typology of clinician-researcher dual-role experiences in health research with patient-participants. Medical Research Methodology 16: 95.DOI: 10.1186/s12874-016-0203-6.

Heppner, M. J., D. Lee, P. P. Heppner, L. C. McKinnon, K. D. Multon and N. C. Gysbers. 2004. The role of problem-solving appraisal in the process and outcome of career counseling. Journal of Vocational Behavior 65: 217-238. doi: 10.1016/S0001-87910300100-3.

Hsiung, P. C. 2008. Teaching reflexivity in qualitative interviewing. Teaching Sociology 36: 211-236.

Jantzer, A. M., D. J. Price-Stalides and P. J. Rottinghaus. 2009. An exploration of social cognitive mechanisms gender and vocational identity among eighth graders. Journal of Career Development 36: 114-138.

Kelly, K. R. and W. C. Lee. 2005. Relations of psychological type to career indecision among university students. Journal of Psychological Type 64: 11-20.

Kelly, K. R. and Y. J. Shin. 2009. Relation of neuroticism and negative career thoughts and feelings to lack of information. Journal of Career Assessment 17: 201-213. doi: $10.1177 / 1069072708329029$.

Kernis, M. H. and B. M. Goldman. 2006. A multicomponent conceptualization of authenticity: Theory and research. Advances in Experimental Psychology 38: 283-356.

Kewley, E. P. 2006. The dual role of psychologist-researcher: Using psychological assessments for research purposes. Master of Counselling. Faculty of Education, Lethbridge Alberta.

Krumboltz, J. D. 1993. Integrating career and personal counseling. The Career Development Quarterly 42: 143-148.

Krumboltz, J. D. 2015. The purpose of career counseling. Career Convergence Magazine April: 3-4. 
Lent, R. W. and S. D. Brown. 2013. Social cognitive model of career self-management: Toward a unifying view of adaptive career behavior across the life span. Journal of Counseling Psychology 60: 557-568.

Lent, R. W., I. Ezeofor, M. A. Morrison, L. T. Penn and G. W. Ireland. 2016. Applying the social cognitive model of career self-management to career exploration and decision-making. Journal of Vocational Behavior 93: 47-57.

Maree, J. G. 2012. A guided meta-reflection theory of career counselling: A case study. South African Journal of Higher Education 26: 670-690.

Maree, J. G. 2013. Counselling for career construction: Connecting life themes to construct life portraits. Turning pain into hope. Rotterdam, The Netherlands: Sense.

Maree, J. G. 2014. Poverty and life designing. In Handbook of the life design paradigm: From practice to theory, ed. L. Nota and J. Rossier, 233-248. Boston, MA: Hogrefe.

Maree, J. G. 2015. The career interest profile. Version 5. Randburg, South Africa: JvR Psychometrics.

Maree, J. G. 2016. Career construction counselling with a mid-career black male. Career Development Quarterly 64: 20-35.

Maree, J. G. 2017a. Life design: The essence of helping people live successful lives and make social contributions. In Understanding educational psychology, ed. I. Eloff and E. Swart. Cape Town, South Africa: Juta.

Maree, J. G. (Ed.). 2017b. Handbook of career adaptability employability and resilience. New York, NY: Springer.

Maree, J. G. and N. Taylor. 2016a. Development of the Maree Career Matrix: A new interest inventory. South African Journal of Psychology 464: 462-476.

Maree, J. G. and N. Taylor. 2016b. Manual for the Maree Career Matrix (MCM). Randburg SA: JvR Psychometrics.

Masdonati, J., K. Massoudi and J. Rossier. 2009. Effectiveness of career counseling and the impact of the working alliance. Journal of Career Development 36: 183-203. doi: 10.1177/0894845309340798.

Miller, A. and P. Rottinghaus. 2014. Career indecision meaning in life and anxiety: An existential framework. Journal of Career Assessment 222: 233-247.

Morgan, T. and D. Ness. 2003. Career decision-making difficulties of first-year students. https://www.researchgate.net/publication/284330989_Career_decision_making_difficulties_of_f irst_year_students

Obi, O. 2015. Constructionist career counseling of undergraduate students: An experimental evaluation. Journal of Vocational Behavior 88: 215-219.

Olivera-Celdran, P. 2011. Purpose in life and career indecision as predictors of academic success in college. Unpublished doctoral dissertation The University of North Carolina, Charlotte, NC.

Oyserman, D., D. Bybee and K. Terry. 2006. Possible selves and academic outcomes: How and when possible selves impel action. Journal of Personality and Social Psychology 91: 188-204.

Patterson-Mills, S. 2014. Ethics in a nutshell. NCDA Career Developments 302: 24-25.

Patton, M. Q. 2002. Qualitative evaluation and research methods. 5th Edition. Newbury Park, CA: Sage Publications Inc.

Picard, F. 2012. Reducing academic and career indecision: The effectiveness of a first-year college program. The Online Journal of Counselling and Education 13.

Rehfuss, M. C. 2009. The future career autobiography: A narrative measure of career intervention effectiveness. The Career Development Quarterly 58(1): 82-90.

Rehfuss, M. and A. Di Fabio. 2012. Validating the future career autobiography as a measure of narrative change. Journal of Career Assessment 20: 452-462. 
Savickas, M. L. 1993. Career counseling in the postmodern era. Journal of Cognitive Psychotherapy: An International Quarterly 7: 205-215.

Savickas, M. L. 2001. Toward a comprehensive theory of career development: Disposition concerns and narratives. In Contemporary models in vocational psychology: A volume in honor of Samuel $\mathrm{H}$. Osipow, ed. F. T. L. Leong and A. Barak, 295-320. Mahwah NJ: Lawrence Erlbaum.

Savickas, M. L. 2005. The theory and practice of career construction. In Career development and counseling: Putting theory and research to work, ed. S. D. Brown and R. W. Lent, 42-70. Hoboken, NJ: Wiley.

Savickas, M. L. 2009. Career-style counselling. In Adlerian counselling and psychotherapy: A practitioner's approach, ed. T. J. Sweeney, 183-207. 5th Edition. New York NY: Routledge.

Savickas, M. L. 2011a. Career counseling. Washington: American Psychological Association.

Savickas, M. L. 2011b. New questions for vocational psychology: Premises paradigms and practices. Journal of Career Assessment. DOI: 10.1177/1069072710395532.

Savickas, M. L. 2012. Life design: A paradigm for career intervention in the 21st century. Journal of Counselling and Development 90: 13-19.

Savickas, M. L. 2014. Career counseling: Guida teorica e metodologica per il XXI secolo. Trento, Italy: Erickson.

Savickas, M. L. 2015a. Career counselling paradigms: Guiding developing and designing. In The APA handbook of career intervention, Vol. 1, ed. P. Hartung, M. Savickas and W. Walsh, 129-143. Washington DC: APA Books.

Savickas, M. L. 2015b. Life-design counselling manual. Rootstown, OH: n.p.

Savickas, M. L. 2016a. Meaning at work: Work at meaning. Closing keynote presentation National Career Development Association Conference Chicago United States of America.

Savickas, M. L. 2016b. Reflection and reflexivity during life-design interventions: Comments on career construction counseling. Journal of Vocational Behavior 97: 84-89.

Savickas, M. L., L. Nota, J. Rossier, J.-P. Dauwalder, M. E. Duarte, J. Guichard ... A. E. M. Van Vianen. 2009. Life designing: A paradigm for career construction in the 21th century. Journal of Vocational Behavior 75: 239-250.

Sieck, B. C. 2012. Obtaining clinical writing informed consent versus using client disguise and recommendations for practice. Psychotherapy 49: 3-11. doi:10.1037/a0025059.

Soresi, S., L. Nota, L. Ferrari and V. S. Solberg. 2008. Career guidance for persons with disabilities. In International handbook of career guidance, ed. J. A. Athanasou and R. van Esbroeck. Dordrecht, The Netherlands: Springer.

Subich, L. M. 2011. Tracing the evolution of career counseling theory. Paper presented in P. J. Hartung Chair. Career counseling. Definitions and new directions. Paper read at the 119th annual meeting of the American Psychological Association Washington D.C.

Super, D. E. 1957. The psychology of careers. New, York NY: Harper.

Taber, B. J., P. J. Hartung, H. Briddick, W. C. Briddick and M. C. Rehfuss. 2011. Career style interview: A contextualized approach to career counseling. The Career Development Quarterly 59: 274-287.

Whiston, S. C. and C. S. Rose. 2015. Career counseling process and outcome. In APA Handbook of career intervention, Vol. 1, ed. P. J. Hartung, M. L. Savickas and W. B. Walsh, 43-60. Washington, DC: APA Books.

White, N. J. and T. J. G. Tracey. 2011. An examination of career indecision and application to dispositional authenticity. Journal of Vocational Behavior 78: 219-224.

Wolfe, I. 2017. Entrepreneurs network interview: What will the future of work and jobs look like? www.perfectlaborstorm.com/2016/12/future-jobs-future-work

Wood, A. M., J. Maltby, M. Caliousis, P. A. Linley and S. Joseph. 2008. The authentic personality: A theoretical and empirical conceptualization and the development of the authenticity scale. Journal 
of Counseling Psychology 55: 385-399.

Xu, H. and T. J. G. Tracey. 2017. The reciprocal dynamic model of career decision ambiguity tolerance with career indecision: A longitudinal three-wave investigation. Journal of Counseling Psychology. Advance online publication. http://dx.doi.org/10.1037/cou0000220 